\title{
Histological analysis of explanted implant-bone interface: a case report
}

\author{
Dae-Dong Kim¹, Dae-Young Kang1, In-Woo Cho', Young-Gyun Song², Hyun-Seung Shin, Jung-Chul Park ${ }^{1 *}$ \\ 'Department of Periodontology, College of Dentistry, Dankook University, Cheonan, Republic of Korea \\ 2Department of Prosthodontics, College of Dentistry, Dankook University, Cheonan, Republic of Korea
}

Osseointegration has been reported to be a dynamic process in which the alveolar bone comes in direct contact with the implant. Various methods were tried to evaluate degree of osseointegration and the measurement of bone-implant contact (BIC) have been commonly used among them. To properly assess the BIC, only histologic analysis is available. However, few studies evaluated BIC of successfully osseointegrated implants in humans. Thus, this is a unique opportunity when implants should be explanted due to inappropriate positioning of implant, presence of pain or sensory disturbance, or broken screw or fixture. This report presents a case of the implant underwent 3-year functional load and a histologic analysis after the fixture fracture. The histomorphometric analysis revealed $53.1 \%$ of BIC measured along the whole implant and $70.9 \%$ measured only in subcrestal area, respectively. In the present study, although the implant was fractured, a high degree of BIC was observed. (J Dent Rehabil Appl Sci 2019;35(4):235-43)

Key words: osseointegration; dental implant; alveolar bone; humans; histology; analysis

\section{Introduction}

Osseointegration has been reported to be a dynamic process in which the alveolar bone come in direct contact with the placed implant surface. ${ }^{1}$ This phenomenon has also been demonstrated in various preclinical models ${ }^{2,3}$ and histologic reports in a few humans. ${ }^{4-6}$ However, the status of osseointegration does not accurately specify the amount of ideal contact ratio between the implant surface and the bone, thus various methods have been proposed to evaluate the degree of osseointegration. ${ }^{7,8}$

Donath and Breuner proposed the Sage-Schliff (sawing and grinding) technique producing undecalcified specimen to investigate the interface between the implant surface and surrounding alveolar bone . This technique has provided a fundamental method

*Correspondence to: Jung-Chul Park

Professor, Department of Periodontology, College of Dentistry, Dankook University, 119 Dandae-ro, Dongnam-gu, Cheonan, 31116, Republic of Korea

Tel: +82-41-550-1931, Fax: +82-303-3442-7364, E-mail: jcp@dent.dku.edu

Received: August 31, 2019/Last Revision: September 14, 2019/Accepted:

September 23, 2019 to evaluate bone-implant contact (BIC), and as a result, the degree of osseointegration can be assessed histologically.

For successful implant treatment, it is essential to obtain substantial osseointegration and secondary stability of the implant over long-term period. Although BIC does not represent the overall osseointegration status in clinical situation, however, it is generally accepted that higher BIC is recommended for long-term success of dental implant.

As mentioned above, it is important to understand the bone-to-implant interaction in patients showing successful treatment outcome of implant. However, only histological analysis can properly assess biochemical host response and the value of BIC, and the researchers had difficulty to retrieve the successfully osseointegrated implants from the patients

Copyright(C) 2019 The Korean Academy of Stomatognathic Function and Occlusion. (c) It is identical to Creative Commons Non-Commercial License. 
due to ethical reasons. Therefore, there are few, if any, studies which evaluated histologic BIC of successfully osseointegrated implants in humans and these specimens can only be obtained under limited conditions requiring explantation such as implants placed in an inappropriate position, causing pain or sensory disturbance, or showing fracture of screw or fixture. ${ }^{10}$ Thus, performing a histologic analysis of these implants is a unique opportunity to assess osseointegration through $\mathrm{BIC}$ measurements and to identify the biomechanical interaction between the implant and bone.

The current study is a clinical histological case report of retrieved implant which was fractured after 3-year functional load.

\section{Case Report}

This study was approved by the Institutional Review Board (IRB) at Dankook University (IRB No. DKUDH IRB 2019-06-002).

\section{Clinical Observation}

A female patient, 60-years old, came to department of periodontology, Dankook University dental hospital with missing tooth on \#36 and wanted treatment using dental implant. The tooth had been extracted because of periapical lesion a year ago. After careful clinical and radiographical examination, a ø $4.5 \times 8.5$ $\mathrm{mm}$ bone-level implant $\left(\operatorname{Luna}^{\circledR}\right.$, Shinhung, Seoul, Korea) was placed according to one-stage protocol (Fig. 1). The implant-supported prosthesis was placed four months later.
During three years after prosthesis delivery, no signs or symptoms were shown in annual followup (Fig. 2). However, after three years of function, the patient returned to the clinic with the complaint of loose implant (Fig. 3). From the clinical and radiographic examination, the marginal bone loss was observed with probing depth of $4-5 \mathrm{~mm}$, and it was suspected that the fixture collar and abutment screw had been fractured. Due to the failure to remove the fractured screw with the removal kit, less invasive implant retrieval was not feasible. As a result, the explantation of the implant using trephine bur followed by alveolar ridge preservation were planned. After the explantation using 5-mm diameter trephine bur (Trephine kit, GenOss, Seoul, Korea), the socket was thoroughly debrided and open healing alveolar ridge preservation was performed using $250 \mathrm{mg}$ of deproteinized bovine bone mineral with $10 \%$ porcine collagen (Bio-Oss Collagen, Geistlich, Wolhusen, Switzerland) and resorbable collagen membrane (Collagen graft, GenOss, Seoul, Korea) (Fig. 4). Five-month

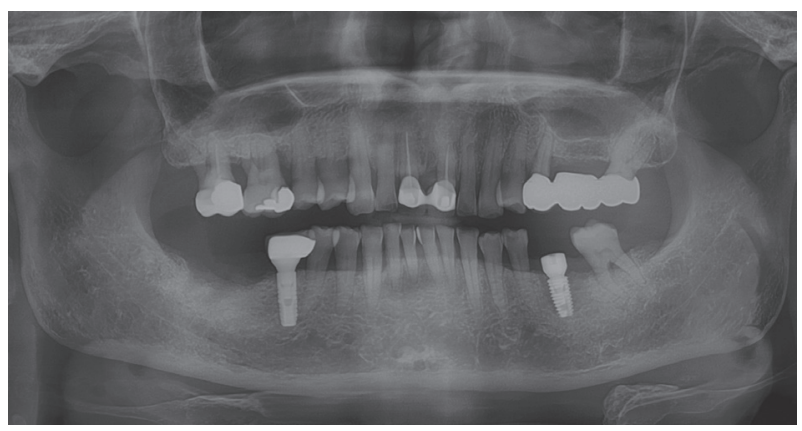

Fig. 1. Panoramic radiograph after implant placement (\#36).
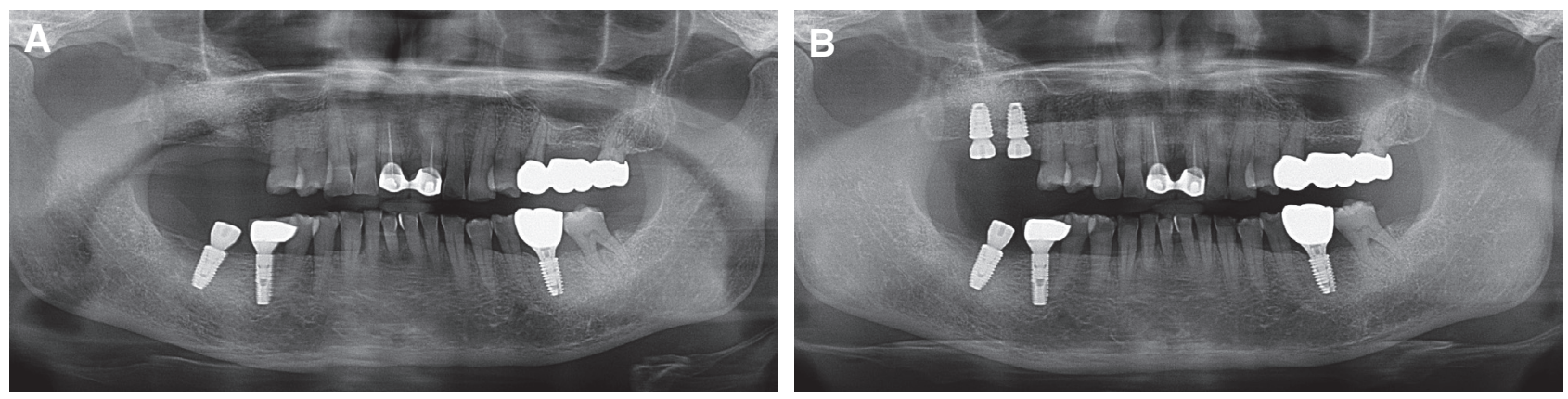

Fig. 2. Panoramic radiograph. (A) 1 year recall after implant placement, (B) 1.5 years recall. 

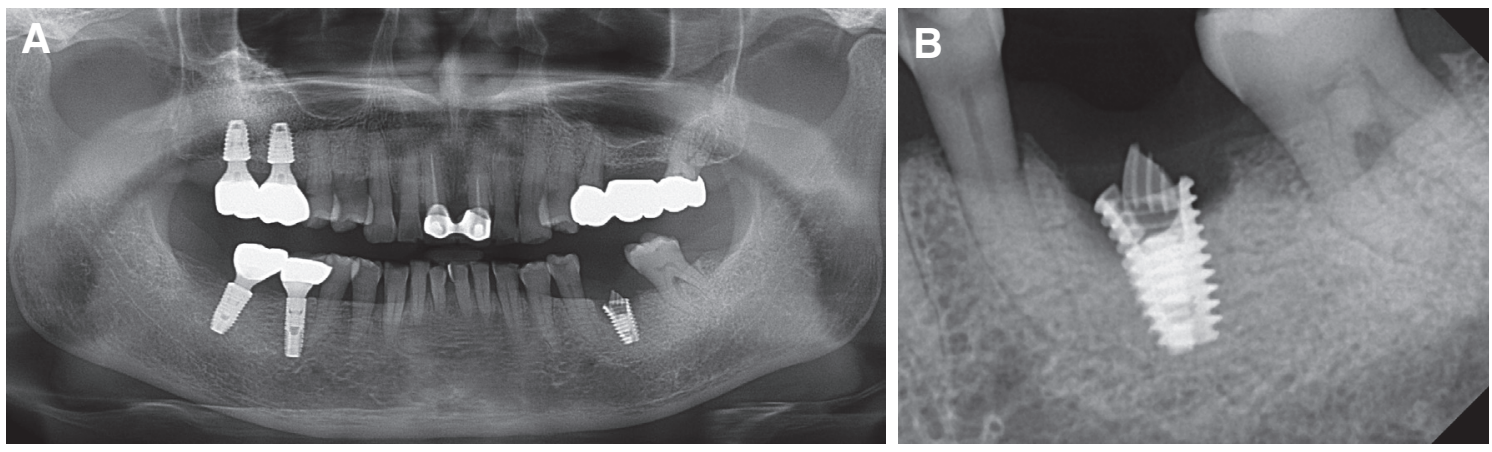

Fig. 3. Radiographs when returned to the clinic with the complaint of loose implant 3.5 years after implant placement. (A) Paroramic view, (B) Periapical view.
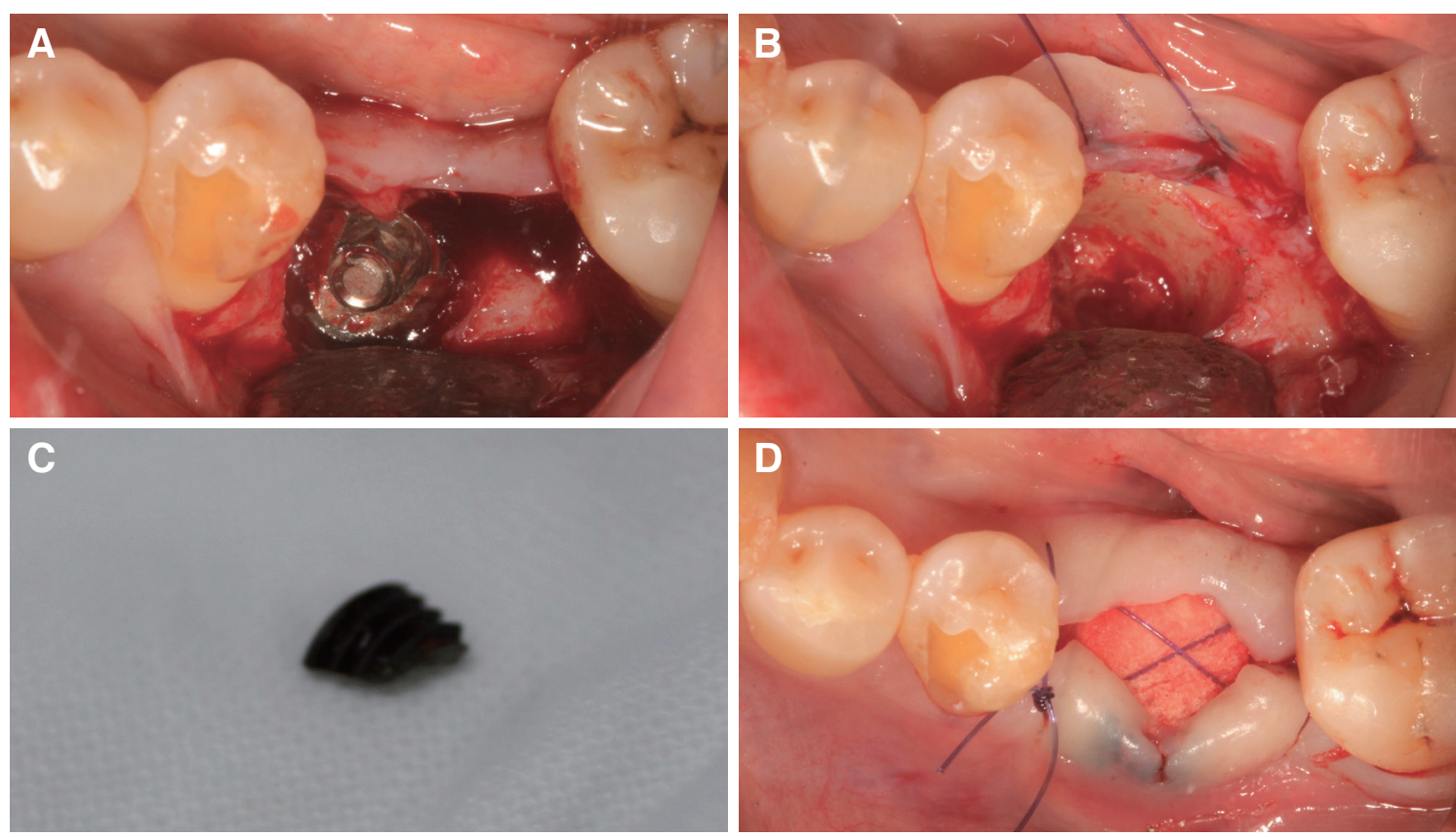

Fig. 4. Clinical photographs illustrating surgical procedure. (A) After flap reflection. Granulation tissue around fractured implant fixture can be observed, (B) After explantation using trephine bur, (C) Removed fragment of implant fixture, (D) After alveolar ridge preservation with deproteinized bovine bone mineral with 10\% porcine collagen (Bio-Oss Collagen, Geislitch, Wolhusen, Switzerland) and resorbable collagen membrane (Collagen graft, GenOss, Seoul, Korea).

after the alveolar ridge preservation, a new ø $5.0 \times$ $8.5 \mathrm{~mm}$ bone-level implant (Luna ${ }^{\circledR}$, Shinhung, Seoul, Korea) was placed by one-stage protocol without any further ridge augmentation procedure (Fig. 5, 6).

\section{Histologic processing}

The specimen including implant fixture was fixed in neutral-buffered formalin for 2 weeks and dehydreated in ascending concentrations of ethanol. The dehydrated specimen was embedded in light-curing one-component composite resin and sectioned from the center of sample using a diamond saw (EXAKT 300 CP, Apparatebau, Norderstedt, Germany). The section was reduced to a final thickness of $40 \mu \mathrm{m}$ by microgrinding with a grinding device (KULZER EXAKT 400 CS, Apparatebau, Norderstedt, Germany). The specimen was stained with the Goldner trichrome stain. 

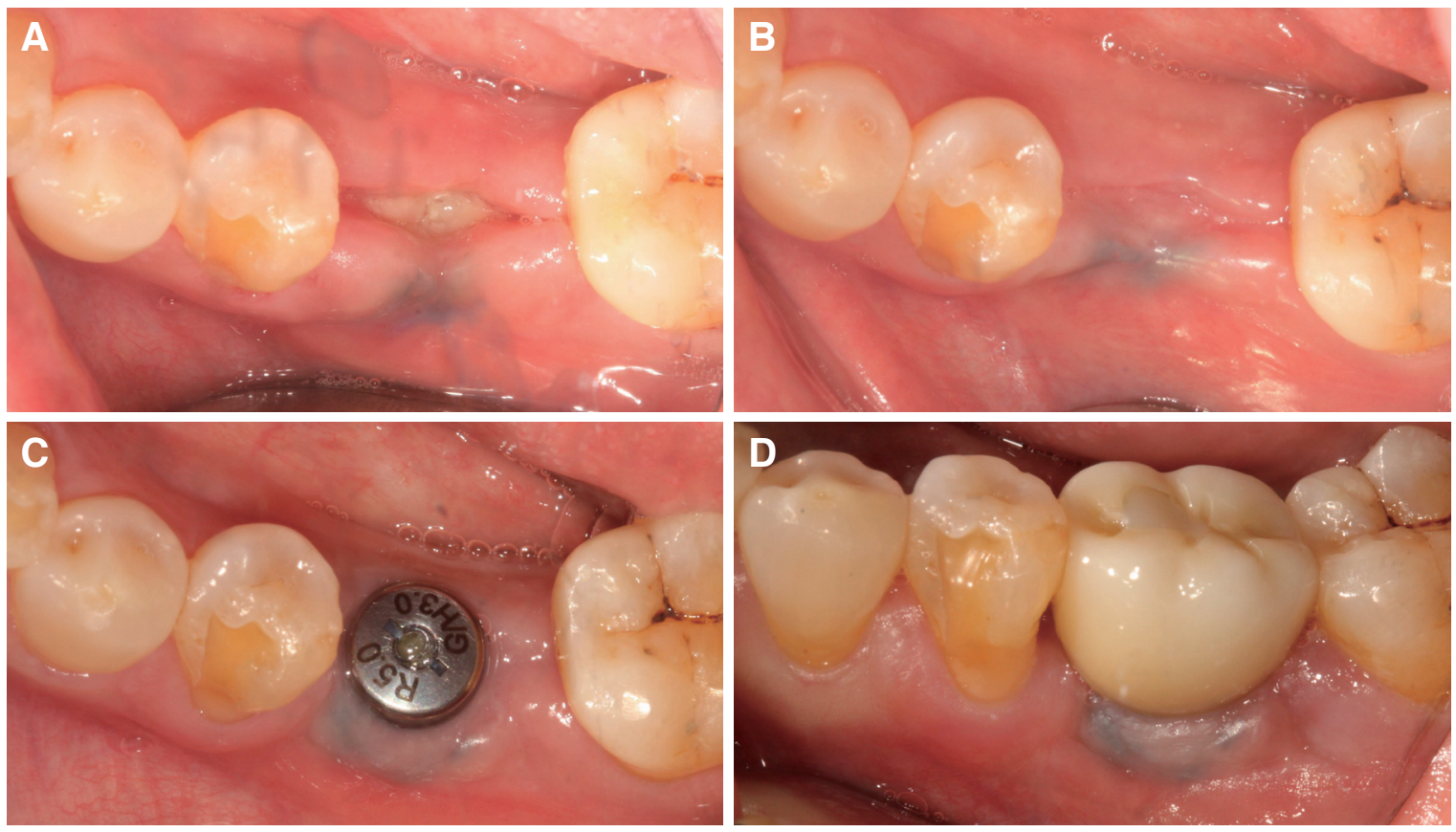

Fig. 5. Clinical photographs illustrating surgical procedure. (A) 2 weeks after alveolar ridge preservation, (B) 5 months after alveolar ridge preservation, (C) After 1-stage implant surgery, (D) After final crown placement.
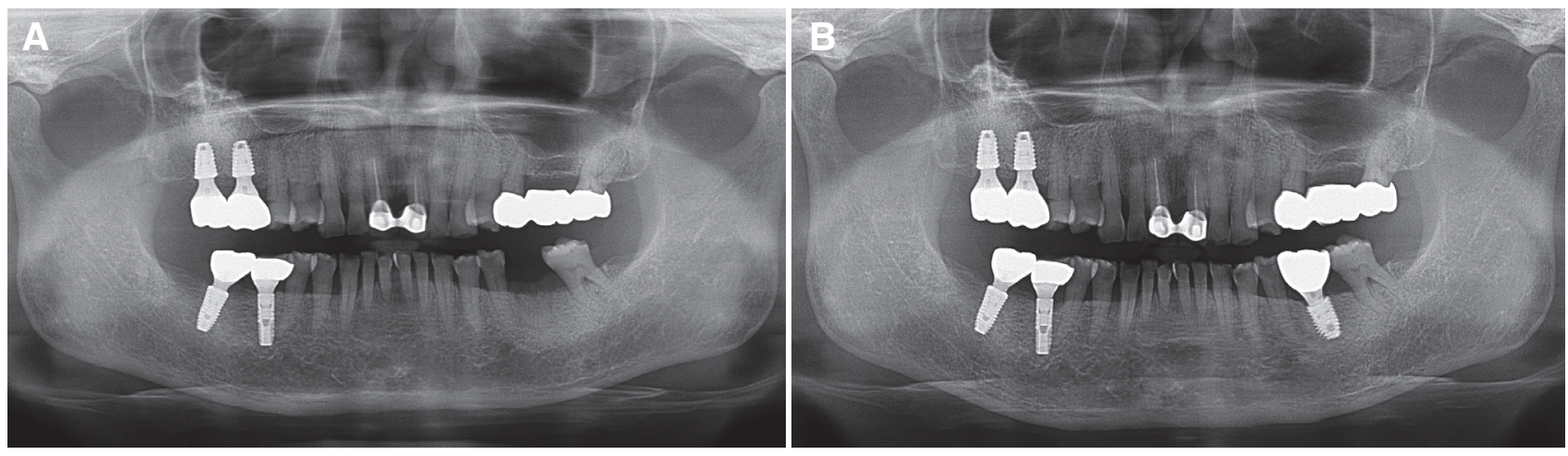

Fig. 6. Paroramic radiographs. (A) Immediately after explantation and alveolar ridge preservation, (B) After final crown placement.

\section{Histologic and histomorphometric analysis}

The stained slide was scanned on a digital slide scanning device (Pannoramic 250 Flash III, 3D Histech, Budapest, Hungary), and the image was visualized using viewing software (Caseviewer ver. 2.0, 3D Histech, Budapest, Hungary). For determining percentage of BIC, the regions of BIC along the implant perimeter were divided from the total perimeter in region of interest. The BIC was measured in two ways: including whole implant surface and including only sub-crestal area below the fracture line with $a \times$ 100 magnification

\section{Results}

Clinically, the implant fracture extended beyond fourth thread in buccal aspect (Fig. 4), similar to the abutment fracture line although it seemed to in- 
volve only the first thread on the lingual side (Fig. 7). Based on this level, inflammatory cell infiltration was observed above and peri-implant bone below. The outer area of this bone between the fourth and fifth thread showed a different response to the staining compared to the other bone areas.

Below the fifth thread, close bone-implant contact was observed along irregular implant surface without the intervention of fibrous tissues (Fig. 8A). Upper two inter-thread spaces were filled with dense mature bone (Fig. 8B) and lower two inter-thread spaces were surrounded by band-shaped bone and marrow space (Fig. 8C). Fig. 9 provides magnified views of aforementioned the dense mature bone. Primary osteons had irregularly deposited lamellae and misaligned bone lacunae. Osteocytes were observed in interstitial lamellar bone and around bone-implant interface as well as in the primary osteons. Newlyformed bone could be distinguished by staining characteristic darker than previously-formed one. Irregular cement lines were observed at the boundary of the osteons, the interstitial lamellar bone, or the

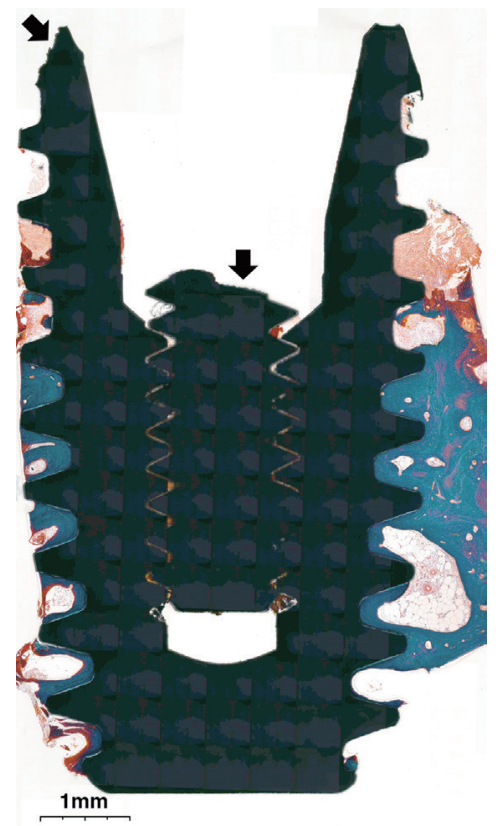

Fig. 7. A general overview of the sectioned specimen (×15). The arrows indicate implant fracture line and abutment screw fracture line, respectively. woven bone. Neither inflammatory cells nor epithelial cells were observed on the bone-implant interface or in the bone.

The overall BIC along the whole implant surface was $53.1 \%$, and the BIC when measured only in subcrestal area was $70.9 \%$.
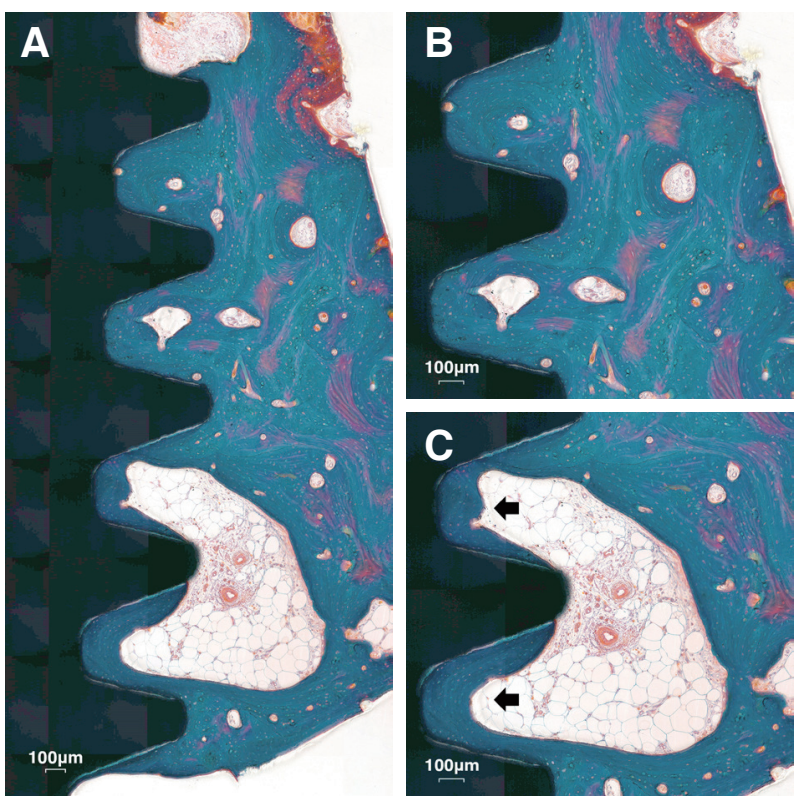

Fig. 8. Medium magnification views of bone tissue in the sectioned specimen. (A) The implant threads are well surrounded by compact mature bone $(\times 40)$. (B) Close contact is continued between the implant surface and the compact bone $(\times 50)$. (C) Implant threads are surrounded by band-shaped bone with marrow space (Black arrows, $\times 50)$.
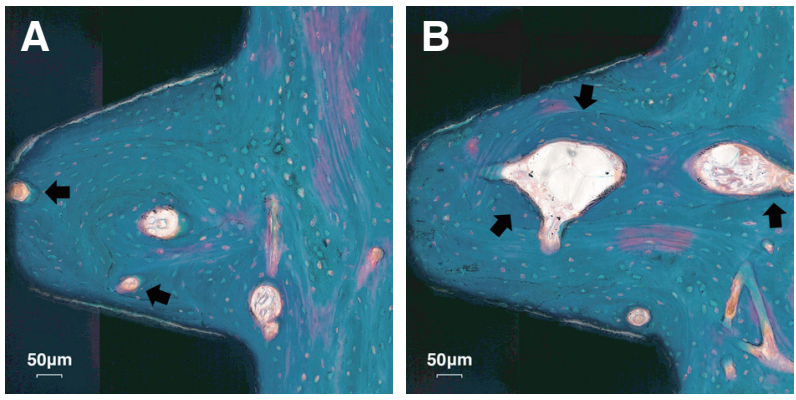

Fig. 9. High magnification views of the sectioned specimen $(\times 100)$. (A) Osteons in contact with the implant surface are observed (Black arrows). (B) Newlyformed bone is demarcated from previously-formed bone by darker staining color (Black arrows). 


\section{Discussion}

It is important to note that the histologic analysis of explanted implants in humans is not only capable of measuring BIC, but also of examining the response at the interface between the implant and bone. ${ }^{11}$ Therefore, the current study provides valuable information to observe the natural bone response to implant, especially under functional load.

Much effort has been devoted to surface modification of implant to increase both the quality and quantity of osseointegration. Studies found that the micro-roughness and porosity of implant surface facilitates not only angiogenesis but also cell migration process, activity, and function, ${ }^{12}$ so that BIC and the degree of mechanical engagement between bone and implant has been improved. ${ }^{2,13}$ Various methods were attempted to obtain such micro-roughness. In the case of surface blasted with aluminum oxide $\left(\mathrm{Al}_{2} \mathrm{O}_{3}\right)$, there was a significant increase in the degree of bone attachment under the functional load, and in the acid-etched surface can further increase BIC. ${ }^{2}$ Therefore, most of the recent-marketed implant brands have sandblasted, large-grit, acid-etched surface to improve the BIC, and the histologic analysis of this case was also consistent with other studies using implant with above-mentioned surface.

In the present study, histologic analysis revealed that a dense bone was engaged between implant threads and newly formed bone. The BIC is influenced by various factors such as age, sex, habit, and systemic diseases affecting bone metabolism of the patient. There is lack of evidence regarding critical percentage of BIC for achieving osseointegration needed to successfully stabilize implants. The BIC in the above sample was $70.9 \%$, which is consistent with the high BIC reported in other studies. Brunel et al reported $74 \%$ of BIC with hydroxyapatitie coated implant under 14 months loading, ${ }^{5}$ and Hayakawa et al also reported a similar results with sandblasted, acid etched implant. ${ }^{14}$ Although there was a fracture at the implant body, the remaining surface showed equally high BIC along the surface. At this moment, it is not clear why the implant fixture has broken, however, the remaining fixture appeared well-inte- grated. Further studies are needed to determine how much BIC is clinically necessary for successful maintenance of implant.

Various methods have been introduced to remove successfully osseointegrated implants including counter-torque ratchet, piezo tips, high-speed burs, forceps, and trephine bur. The bone removal techniques like using piezo tips, high-speed burs, and trephine bur have limitation of being traumatic and of damaging the explantation socket. Therefore, if possible, less invasive techniques like counter-torque ratchet technique and reverse screw technique are recommended for implant removal. However, if these techniques failed to remove the fracture screw, the bone removal techniques should be considered. In the present study, the abutment screw fracture occured below the shoulder of the implants, and the authors failed to engage with the removal kit. Instead, the authors chose to use trephine bur for explantation. As previously stated, the explantation procedure using trephine bur has some risk like overheating. It should be carefully planned and performed under copious irrigation with cooled saline.

A number of studies showed that unfavorable forces during mastication may result in mechanical complications of the implant (i.e. screw fracture, screw loosening, fixture fracture). ${ }^{15}$ When parafunctional load is applied to the implants due to oral habits such as bruxism, a bending force and a torque are generated the implant and the superstructure. In addition, the risks from mechanical load seem to be the highest in the molar region with one or two implant, especially the implants under loading not parallel to major axis of implant from cantilever or heavy occlusal force per se such as bruxism. ${ }^{16}$ As a result, fracture of fixture and/or screw frequently occurs in implants for single tooth replacement. ${ }^{17}$ In addition, the design of implant system, ${ }^{18}$ holes in hollowcylinder implant, ${ }^{19}$ and reduced implant diameter ${ }^{20}$ are also responsible for fracture of the implant. In order to prevent these mechanical complications of the implant, clinicians should consider proper diameter of fixture, adjustment of oral habit, and design and size of implant prosthesis for edentulous site. 


\section{Conclusion}

In the present study, the implant appeared well surrounded by compact mature bone, and high percentage of BIC were observed. Also, the implant surface showed excellent osteoconductivity, as seen almost all threads were filled with compact bone without inflammatory cell infiltration, epithelial cell downgrowth. Within the limitation of the present case, a successful osseointegration have been achieved after a long loading period, showing a positive interaction between bone and implant.

\section{Acknowledgements}

This research was conducted with support from the reserach fund from Dankook University (R-201901136).

\section{ORCID}

Dae-Dong Kim https://orcid.org/0000-0003-0458-9329

Dae-Young Kang https://orcid.org/0000-0002-4311-4118

In-Woo Cho https://orcid.org/0000-0003-4985-3816

Young-Gyun Song https://orcid.org/0000-0003-3789-9585

Hyun-Seung Shin https://orcid.org/0000-0002-1410-9731

Jung-Chul Park https://orcid.org/0000-0002-2041-8047

\section{References}

1. Iezzi G, Piattelli A, Mangano C, Degidi M, Testori T, Vantaggiato G, Fiera E, Frosecchi M, Floris P, Perroni R, Ravera L, Moreno GG, De Martinis E, Perrotti V. Periimplant bone response in human-retrieved, clinically stable, successful, and functioning dental implants after a long-term loading period: a report of 17 cases from 4 to 20 years. Implant Dent 2016;25:380-6.

2. Cordioli G, Majzoub Z, Piattelli A, Scarano A. Removal torque and histomorphometric investigation of 4 different titanium surfaces: an experimental study in the rabbit tibia. Int J Oral Maxillofac Implants 2000;15:668-74.

3. Sakakura CE, Margonar R, Holzhausen M, Nociti FH Jr, Alba RC Jr, Marcantonio E Jr. Influence of cyclosporin A therapy on bone healing around titanium implants: a histometric and biomechanic study in rabbits. J Periodontol 2003;74:976-81.

4. Degidi M, Petrone G, Iezzi G, Piattelli A. Bone contact around acid-etched implants: a histological and histomorphometrical evaluation of two human-retrieved implants. J Oral Implantol 2003;29:13-8.

5. Brunel G, Armand S, Miller N, Rue J. Histologic analysis of a fractured implant: a case report. Int J Periodontics Restorative Dent 2000;20:520-6.

6. Degidi M, Petrone G, Iezzi G, Piattelli A. Histologic evaluation of a human immediately loaded titanium implant with a porous anodized surface. Clin Implant Dent Relat Res 2002;4:110-4.

7. Sennerby L, Ericson LE, Thomsen P, Lekholm U, Astrand P. Structure of the bone-titanium interface in retrieved clinical oral implants. Clin Oral Implants Res 1991;2:103-11.

8. Johansson CB, Hansson HA, Albrektsson T. Qualitative interfacial study between bone and tantalum, niobium or commercially pure titanium. Biomaterials 1990;11:277-80.

9. Donath K, Breuner G. A method for the study of undecalcified bones and teeth with attached soft tissues. The Säge-Schliff (sawing and grinding) technique. J Oral Pathol 1982;11:318-26.

10. Shah $\mathrm{FA}$, Nilson $\mathrm{B}$, Brånemark $\mathrm{R}$, Thomsen $\mathrm{P}$, Palmquist A. The bone-implant interface - nanoscale analysis of clinically retrieved dental implants. Nanomedicine 2014;10:1729-37.

11. Mangano FG, Pires JT, Shibli JA, Mijiritsky E, Iezzi G, Piattelli A, Mangano C. Early bone response to dual acid-etched and machined dental implants placed in the posterior maxilla: a histologic and histomorphometric human study. Implant Dent 2017;26:24-9.

12. Schwartz Z, Lohmann C, Oefinger J, Bonewald LF, Dean DD, Boyan BD. Implant surface characteristics modulate differentiation behavior of cells in the osteoblastic lineage. Adv Dent Res 1999;13:3848.

13. Buser D, Schenk RK, Steinemann S, Fiorellini JP, Fox $\mathrm{CH}$, Stich H. Influence of surface characteristics on bone integration of titanium implants. 
A histomorphometric study in miniature pigs. J Biomed Mater Res 1991;25:889-902.

14. Hayakawa T, Kiba H, Yasuda S, Yamamoto H, Nemoto K. A histologic and histomorphometric evaluation of two types of retrieved human titanium implants. Int J Periodontics Restorative Dent 2002;22:164-71.

15. Schwarz MS. Mechanical complications of dental implants. Clin Oral Implants Res 2000;11:156-8.

16. Rangert B, Krogh PH, Langer B, Van Roekel N. Bending overload and implant fracture: a retrospective clinical analysis. Int J Oral Maxillofac Implants 1995;10:326-34.

17. Balshi TJ, Wolfinger GJ. Two-implant-supported single molar replacement: interdental space require- ments and comparison to alternative options. Int J Periodontics Restorative Dent 1997;17:426-35.

18. Steflik DE, Parr GR, Singh BB, Lake FT, Sisk AL, Howell FV, Shelton TW. Light microscopic and scanning electron microscopic analyses of dental implants retrieved from humans. J Oral Implantol 1994;20:8-24.

19. Piattelli A, Scarano A, Piattelli M, Vaia E, Matarasso S. Hollow implants retrieved for fracture: a light and scanning electron microscope analysis of 4 cases. J Periodontol 1998;69:185-9.

20. Eckert SE, Meraw SJ, Cal E, Ow RK. Analysis of incidence and associated factors with fractured implants: a retrospective study. Int J Oral Maxillofac Implants 2000;15:662-7. 


\section{임플란트 매식체 파절로 제거된 임플란트 골계면의 조직학적 분석 증례}

\section{김대동 ${ }^{1}$, 강대영', 조인우 ${ }^{1}$, 송영균 ${ }^{2}$, 신현승 ${ }^{1}$, 박정철 $^{1 *}$}

${ }^{1}$ 단국대학교 치과대학 치주과학교실

${ }^{2}$ 단국대학교 치과대학 보철학교실

골유착은 기능 하중을 받는 임플란트에 치조골이 직접적으로 접촉하는 역동적인 과정이라고 보고되었다. 골유착을 평가 하기 위한 다양한 방법들이 시도되었고 그 중 골-임플란트 접촉 비율을 측정하는 방법이 가장 흔히 사용되고 있다. 골-임 플란트 접촉 비율은 조직학적 분석을 통해서만 측정이 가능하지만 인간에서 성공적으로 골유착을 형성한 임플란트에 조 직학적 분석을 시행한 연구는 많지 않다. 임플란트가 부적절한 위치에 식립되었거나, 식립 후 통증이나 감각 장애가 있는 경우, 임플란트 구조물이 파절된 경우와 같이 임플란트 제거가 필요한 경우에서만 골-임플란트 접촉 비율을 측정할 수 있기에 이는 매우 특별한 기회라고 할 수 있다. 본 증례에서는 3 년간의 기능 하중을 받은 후 매식체 파절로 제거된 임플 란트에서 조직학적 분석을 시행하였다. 조직 형태학적 연구 결과 임플란트 전체를 기준으로 골-임플란트 접촉 비율을 측 정한 경우 대비 치조제 하부만 포함하여 골-임플란트 접촉 비율을 측정한 경우 각각 접촉 비율은 $53.1 \%, 70.9 \%$ 로 나타 났다. 본 증례를 통해 비록 임플란트는 파절되었으나 생체 내에서 높은 수치의 골-임플란트 접촉 비율이 확인되었다.

(구강회복응용과학지 2019;35(4):235-43)

주요어: 골유착; 임플란트; 치조골; 인간; 조직학; 분석 